\title{
FROM OBJECT TO IMAGE - IMAGE TO OBJECT: CONCEPTUAL ART
}

\author{
Yurdagül KILIÇ ${ }^{1}$
}

\begin{abstract}
Conceptual art considered to have emerged as a new understanding in the late 1960's and leading to great conflicts within the art world is an understanding which opposes to art's being limited to such specific categories as painting and sculpture and to art works' being exhibited in galleries and museums, and is an understanding where object loses its significance and thought becomes vital. The art movements rising with postmodernism from 20th century onwards caused the object which is the main subject of art to bear different meanings at a different place and a different time. In the age of postmodernism art is everywhere and in everything and thus the limitation to image cannot be considered.The starting point of the conceptual art which developed in opposition to commercialization of art and the formalist art theory has been examined in this study. The information and emerging findings as a result of the scanning of related literature, one of qualitative research methods, has been assessed within this context.
\end{abstract}

Keywords: Conceptual Art, Object, Image, Postmodernism

K1lıç, Yurdagül . "From Object to Image- Image to Object: Conceptual Art". idil 6.30 (2017): 511-527.

Kilıç, Y. (2017). From Object to Image- Image to Object: Conceptual Art. idil, 6 (30), s.511-527.

1 Arş. Gör., Dokuz Eylül Üniv., Güzel Sanatlar Eğitimi Böl., Resim-İş̧ Eğitimi ABD, yurdagul.klc(at)hotmail.com 


\title{
NESNEDEN IMGEYE - IMGEDEN NESNEYE: KAVRAMSAL SANAT
}

\begin{abstract}
öz
1960’lı yılların sonuna doğru yeni bir anlayış olarak ortaya çıktığı düşünülen ve sanat dünyasında oldukça büyük tartışmalara sebep olan Kavramsal Sanat; sanatın resim, heykel gibi özel bir türle sınırlandırılmasına, sanat eserlerinin galerilerde, müzelerde sergilenmesine karşı çıkan, nesnenin önemini yitirdiği, düşüncenin ön plana çıktığı bir anlayıştır. 20. yüzyıldan itibaren Postmodernizmle birlikte boy gösteren sanat akımları, sanatın asıl konusu olarak adlandırılan nesnenin farklı yer ve zamanda farklı anlamlar ifade etmesine sebep olmuştur. Postmodern çağda sanat her yerde ve her şeydedir ve imgelerin sınırlandırılması düşünülemez. Bu çalışmada; uluslararası sanat ortamında etkili olan, sanatın ticarileşmesine ve biçimci sanat kuramına karşı gelişen kavramsal sanatın çıkış noktası incelenmiştir. Nitel araştırma yöntemlerinden biri olan ilgili literatürlerin taranmasıly elde edilen bilgiler ve ortaya çıkan bulgular, bu bağlamda değerlendirilmiştir.
\end{abstract}

Anahtar Kelimeler: Kavramsal Sanat, Nesne, İmge, Postmodernizm 


\section{Introduction}

"Conceptual artwork is good only when the idea is good"

Sol Lewitt

In the industrialization age, in addition to the innovations and developments taking place in social life new pursuits emerged in art with the rapid development of science and technology. As a result of these pursuits, many movements and thoughts such as the conceptual art claimed its place in art world. Actually, it is not so easy to precisely draw the existential borders of Conceptual Art which is assumed to have emerged as a new understanding in the second half of the 20th century,

With the arrival of Cubism, a new form language was established for the hundreds of year old traditional art by going beyond the traditional materials for the first time. Now, daily materials have turned into an object of art. As also stated in the article by Sürmeli, the objects stripping off their meanings and gaining new ones and carried to a conceptual dimension became more prominent with the Dada movement defined as destructiveness (Sürmeli, 2012: 337). Therefore; the necessity between art and the object began to be questioned with the advent of Dadaism, and slowly an understanding appeared where the image became predominant.

Work of art does not exist anymore as a material being, yet the traditional work of art for the conceptual artist portrays the transit station which only bears the thought upon itself, whereas concept in conceptual thought has the right of priority over the form. This immaterialization of art resides, though implicitly, in countless manifestations before the emergence of conceptual art. The perspective of Marcel Duchamp who was interested in ideas and who decided to forsake the physical appearance of painting is the foremost among those. Duchamp became one of the most significant artists of Europe and North America in the twentieth century and was pivotal in laying the foundation of pop art and conceptual art movements in the Post-World War II. It had been one of the main ideas of Duchamp's career to bring down the traditional and accepted methods of work of art by means of irony and ridicule. On the other 
hand, his most striking and iconoclastic production is found objects that had inspired the other artists the most.

Sol Lewitt expresses Conceptual Art as such: "Idea or concept is the most important part of the work of art within the conceptual art... All the planning and decision-makings are carried out beforehand and the application of the idea remains in the second plan. Idea transforms into a machine that makes art." (Lewitt, 1967). Again, Sol Lewitt emphasizes the importance of the concepts with the statement "Conceptual artwork is good only when the idea is good". He also reflected that the objects used in art are not more important than the images. The need for object in art lost its significance to a large extent.

"Conceptual art rather appeals to the eye of the spectator than to the brain" says Joseph Kosuth. In his book Art After Philosophy he states. "All sorts of art conducted following Duchamp is inherently conceptual art. Because, art only exists conceptually" (Kosuth, 1969). J.Kosuth, one of the leading figures of the movement with his works conducted in the name of Conceptual Art, laying emphasis on the importance of thought attempted to express that the work of art is indeed the thought itself. For him, the mind is always at the forefront and art does not solely depend on the object and its formal necessity. Kosuth eliminating the use of object tried to highlight the connection of art to the idea which forms it.

The real matter is not the artworks themselves, but the intellectual and historical resources that enable the way how they are formed.. "As understood by this statement of Hasan Bülent Kahraman; Conceptual art is not related to the material or formal characteristics in its creation but to the meaning and concept conveyed by the work of art. Shortly, What now stand out in conceptual art is not the object, yet the ideas. In his book Modern Art, Michel Ragon (2009) uses the following expressions used by Moles: "Artist no longer creates a work of art, creates the ideas that will create the work of art. "Will work of arts not exist anymore? The work of art in today's community is perhaps the historical remnant of an old community that regards scarcity as the measure. (Ragon, 2009:213).

With the conceptual art the artist feels obligated to adhere to the traditional with respect to the material. The materials found in daily lives are used as art materials. In this period collage, assemblage and photomontage is common. As the products have a character opposing to art and tradition, they are neither sculpture, nor painting, perhaps nor "artwork". The expression of these artists opposition to art manifests itself also with their exhibition of the ready-made. Since the ready-mades come to light with the meaning behind the "thing" which comes into being, they coincide with the emergence of idea which is that of the concept and, this will be decisive for Conceptual Art (Atakan, 1995). 


\section{The Aim and Importance of the Research}

The post-modern discourses began to show itself in all fields of art in the late 20th century. The artworks being created besides these discourses, almost present to us the complexity and limitlessness of today's art merely as a chaos. It is important for the art and the artists of the future to comprehend and interpret the modern art in question.

Thus, the aim of this research is to re-examine the movement of Conceptual Art by detecting the incomplete aspects of the researches conducted so far with regard to the Conceptual Art which still preserves its influence on the art of our present time.

\section{Method}

This research has been carried out via literature-scanning. The findings rising have been evaluated in accordance with the information acquired. In addition to having been limited to post-1960 conceptual art, because of having contained the postmodern period, the research has also touched upon the concepts such as modern and postmodern art. Moreover, philosophical notions and artists that were effective in the movement of conceptual art have been referred to.

\section{Findings and Interpretation}

When we take artwork as an entirety of signs, each of the signs which determines it is required to be a product of artistic sensitivity rather than have a function of intelligibility. Especially in conceptual art and postmodern works, many artists setting off from the conceptual foundations of the language related to the explanation of objective universe, lay emphasis on a new imaginative method described as 'table-concept' (Şahiner, 2008:160).

With the bicycle Wheel, the first ready object displayed in 1913, Duchamp entered a creative process which was the antithesis of artistic talent.

He attempted to keep away from the traditional painting and to reveal the conceptual value of artwork. Object became a work of art, because the artist designed it that way. 


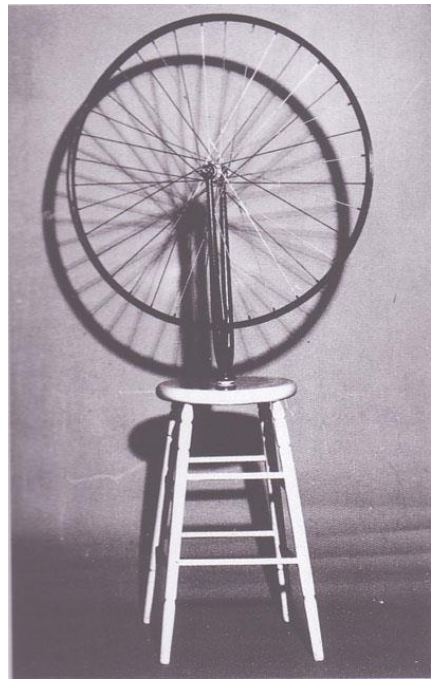

Photo 1: Marcel Duchamp, Bicycle Wheel, 1913, supported ready-made, Bicycle Wheel installed upside down on a stool, original one lost, size unknown.

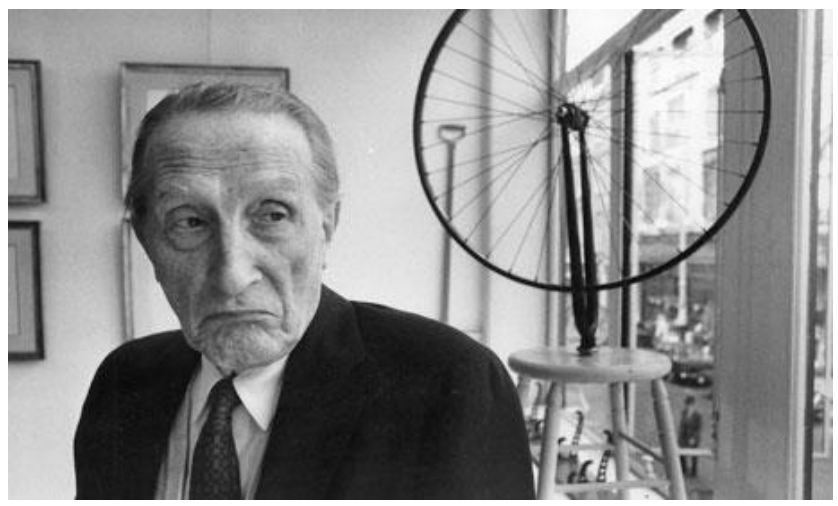

Photo 2: Marcel Duchamp in 1968 with his work Bicycle Wheel. Photograph: Getty

Duchamp in the years 1913-1914 when he desired to "put painting again in the service of the mind", while continuing his work which prepared the "Large Glass", also formed two strange objects. first of these is the "Bicycle Wheel" installed upside down on a stool (Kalkan Erenus, 2014:77). Duchamp stated that he had had no thought towards ready-made in those years, those had not been created for any particular purpose other than fun, that he had had no intention of exhibiting these pieces and expressed that they had not described anything (Cabanne, 2010: 47). Whatever the intention was in unifying them, 
the bicycle wheel isolated from the environment which it was required to be part of in normal conditions isolates as well the stool upon which it was placed. In this new work which bears a different consistency in its own right, Duchamp starts a period of "conceptualization" with "object-subject replacement" by placing an object rather than a subject on the stool (Eroğlu, 2005: 111).

Relocation in physical terms can be interpreted as changing the location in which the object is perceived with an ordinary perspective and as isolating the object by dislocating it from its customary environment. Bicycle wheel is an example that can be evaluated in accordance with this principle (Kalkan Erenus, 2014: 79).

Perhaps another most famous ready object of Duchamp is the upside down "Fountain". This work has pushed the liking of public and the limits of artistic techniques.

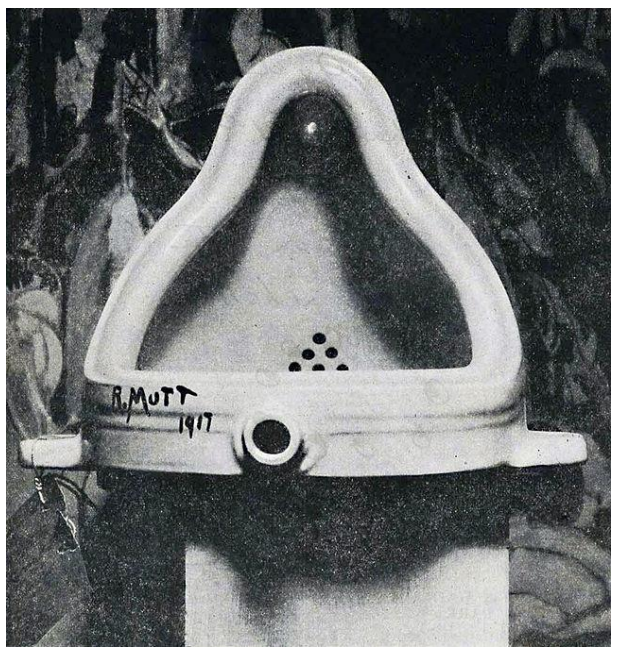

Photo 3: Fountain, M.Duchamp, 1917

Duchamp's most significant artwork is the piece known as Fountain which also gave rise to Pop art, Minimalism, Conceptual Art, Cubism and Dadaism. Fountain, a porcelain urinal, was brought out in 1917 and created a scandal. The work which was put forth with the alias Richard Mutt was selected as the most effective artwork of the 20th century by 500 people from English art circles. The fountain incorporating the German word Armut with 
the meaning poverty also formed a parody. With the urinal losing its function and acquiring an artistic meaning, this work of Dadaism brought down the known art perception and led to Modernism.

As a result, Creating a work of art which is still controversial today, Duchamp also dragged us into the conflict regarding which objects do not belong to Dadaism. This sarcastic disposition of his is clearly seen not only in Fountain but in his addition of a moustache and a beard to the Mona Lisa Painting by Leonardo Da Vinci.

L.H.O.O.Q which he wrote below the painting has a such meaning as " She's got fire down below/her buttocks are on fire" (When it was displayed, incidents occurred in the gallery where it was displayed and Dadaists chanted together their victory songs). Finally uttering the words "you are not as meaningless as you think" he provided us with an answer to the questions.

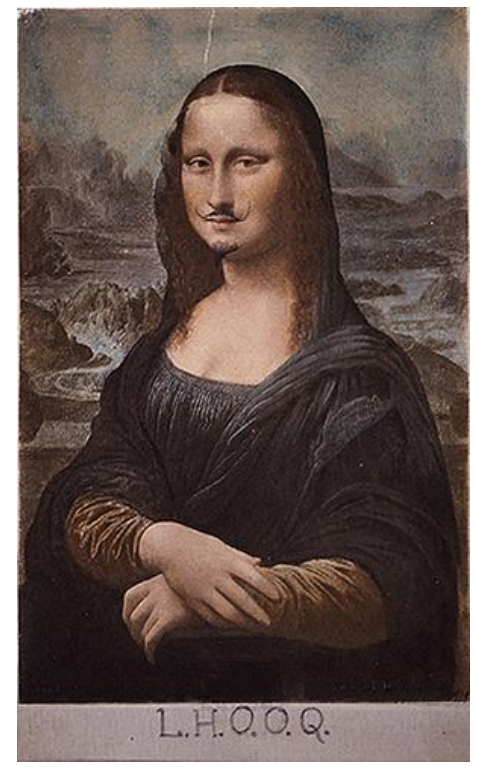

Photo 4: L.H.O.O.Q., M.Duchamp, 1920 


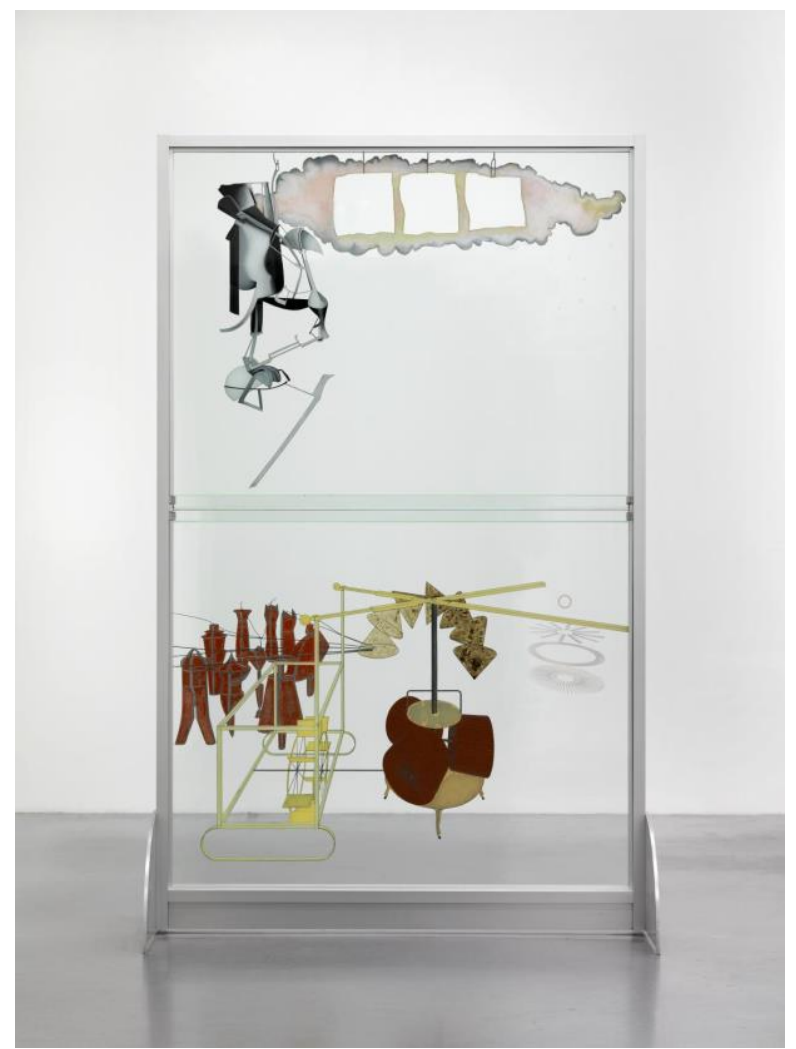

Photo 5: Large Glass, M. Duchamp, 1913

One of the primary attributes of postmodernism in art is the diversity of formal norm and methods. The emphasis laid upon the formal diversity is a part of the lack of broad reliability on modernist aesthetic. Greenberg and others have tried to form a base regarding what the modernism pursues or not for itself. Postmodern theories in art generally focuses on the deep bond between what they include and exclude (Madan, 1997:244). 


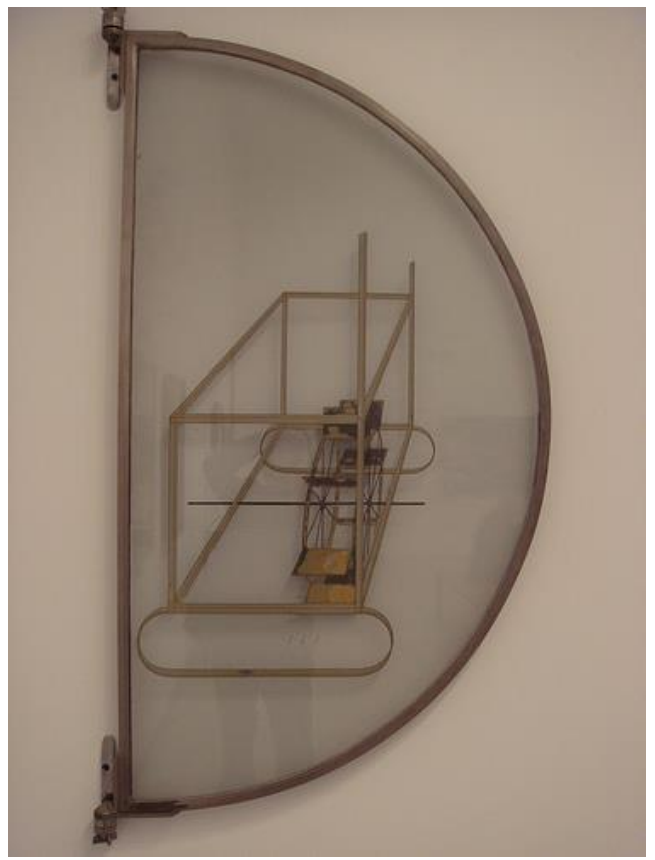

Photo 6: Marcel Duchamp, Glider Containing a Water Mill in Neighboring Metals, 191315 between two glass layers by use of oil paint and lead wire.147x79 cm. Philadelphia Museum of Art, louise ve Walter Arensberg Collection

Another work thought of as some kind of a mould that is to be transferred to a large glass and known with the name, "Glider Containing a water Mill in Neighbouring metals" (1913-1915) has the trait of being the first painting Duchamp employed on a glass. It is done in the form of a half circle between two glass layers by use of oil pint and lead wire. 


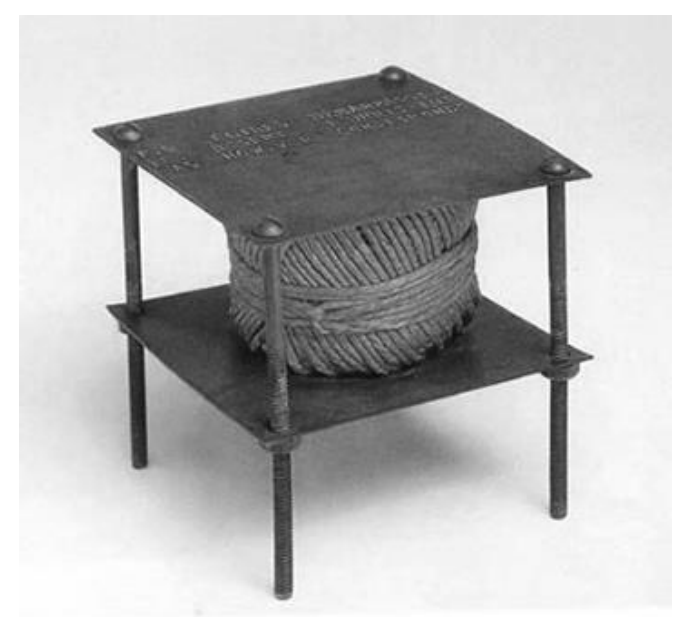

Photo 7: Marcel Duchamp, with hidden noise, 1916, assisted ready-made, a wire ball screwed between two brass plates (along with an unknown object inside), $11,4 \times 12,9 \times 13 \mathrm{~cm}$, Philadelphia Museum of Art, Louise and Walter Arensberg Collection

Dated 1916, assisted ready-made named "With Hidden Noise" is comprised of a wire ball screwed between two brass plates. In a TV interview which Duchamp gives to Sweeney in 1956, he tells that before completing this ready-made, both a prominent collectioner and his friend Walter Arensberg "threw something small into the wire ball without saying what it was and that Duchamp himself did not want to know" and states that this was a little secret between them (Sanouillet: Peterson, 2010: 32). 


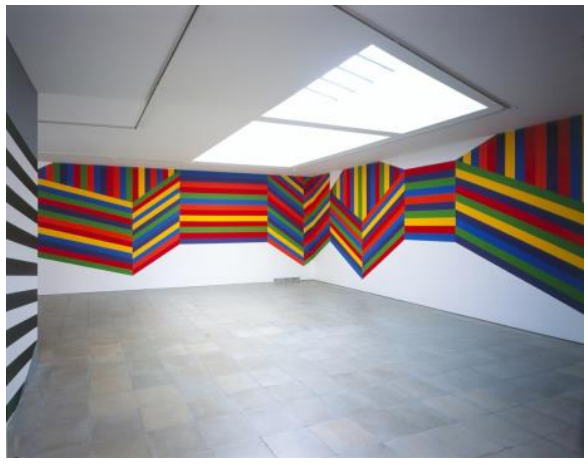

Photo 8: Sol LeWitt, Wall Drawing \#1138: Forms composed of bands of color, 2004Acrylic paint

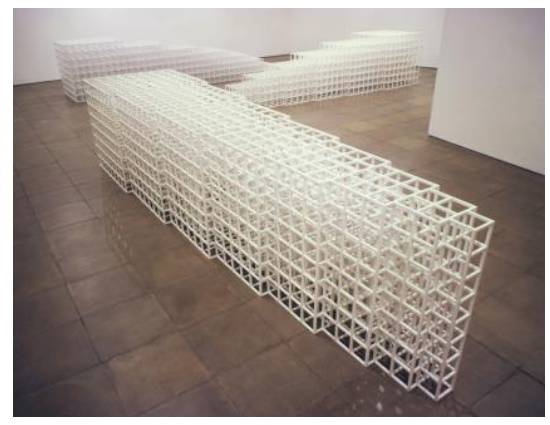

Photo 9 : 11 January - 9 February 1991

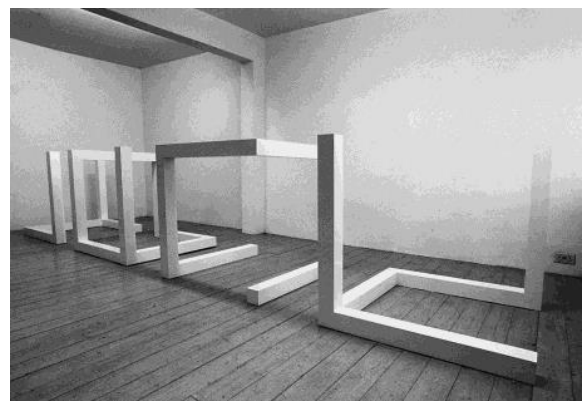

Photo 10: Sol LeWitt: New Works - Structures \& Early Working Drawings10 March - 9 April 1977 installation viewLisson Gallery, London 


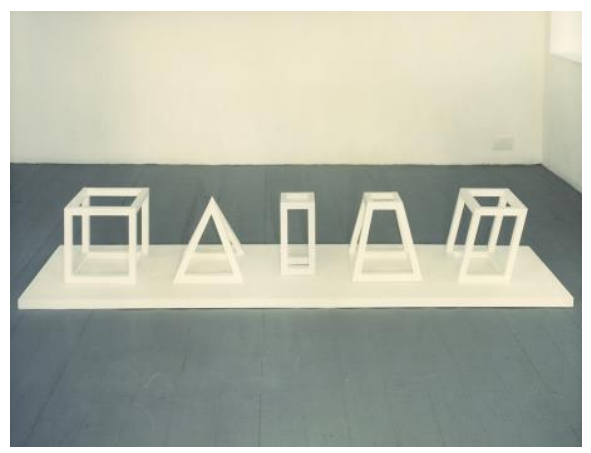

Photo 11: Sol LeWitt24 January - 23 February 1979

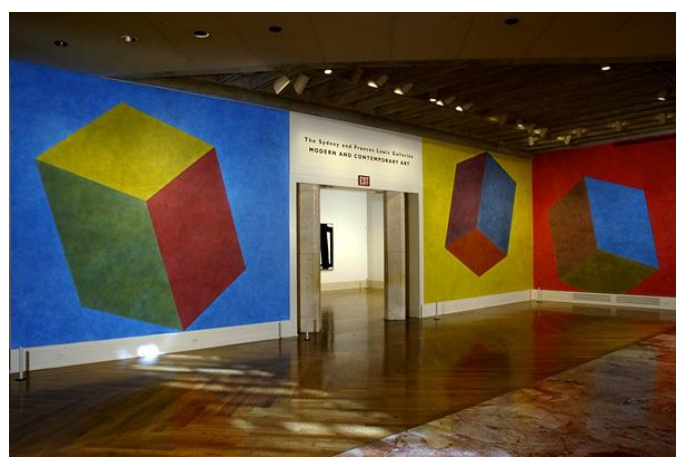

Photo 12: Sol Lewitt Wall Drawing \#541, 1987 (detail) Ink wash on wall Dimensions vary with installation Virginia Museum of Fine Arts, Richmond The Sydney and Frances Lewis Endowment Fund Photo: Travis Fullerton () Virginia Museum of Fine Arts and courtesy of the estate of Sol LeWitt 


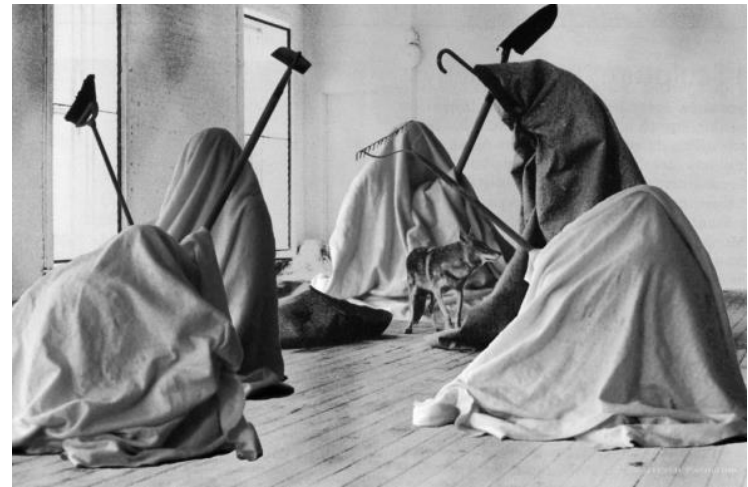

Photo 13: Joseph Beuys

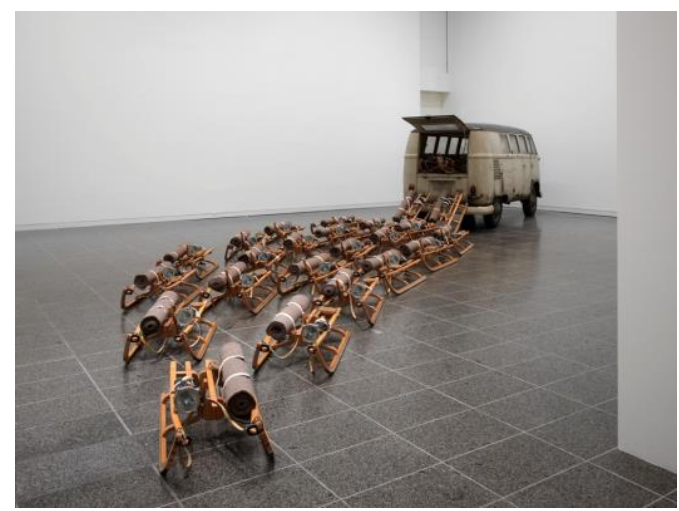

Photo 14: Joseph Beuys, The Pack 1969

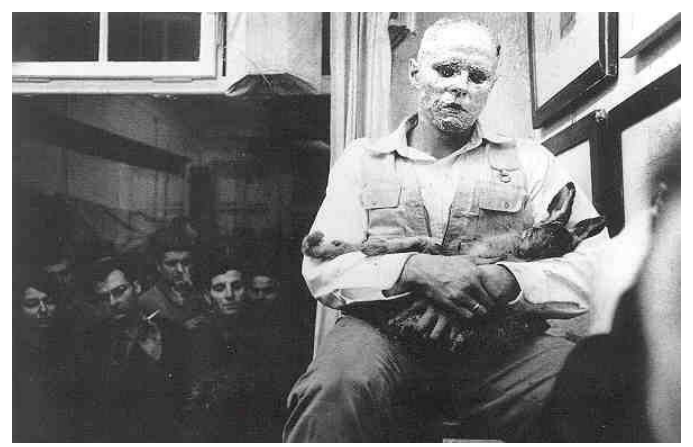

Photo 15: Joseph Beuys, "How to Explain Pictures to a Dead Hare”, Performance, 1965, Duesseldorf. 
German artists Joseph Bueys in this performance implied that explaining art to a dead hare is easier than explaining your problem to a civilized humanity (Antmen, 2008:202).

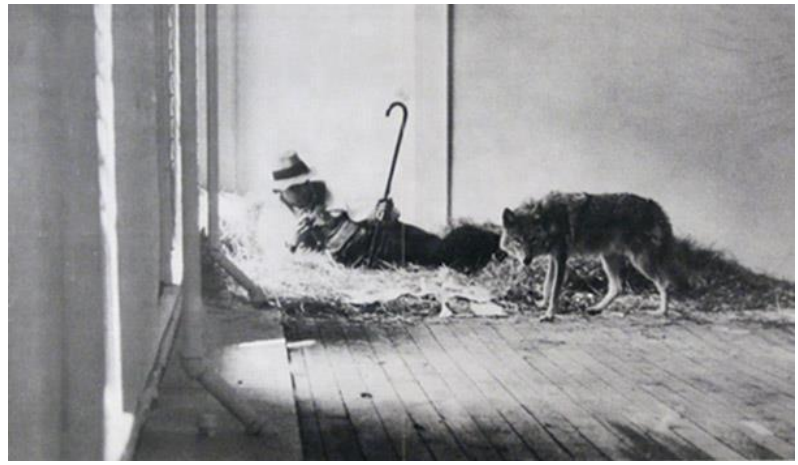

Photo 16: Joseph Beuys,

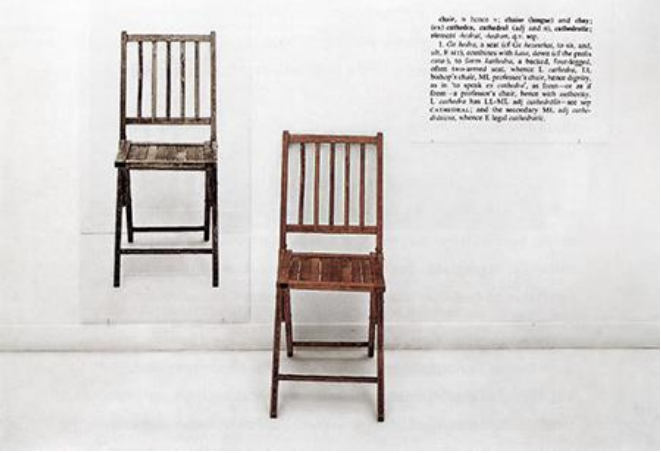

Photo 17: Joseph Kosuth, One and Three Chairs, 1965 


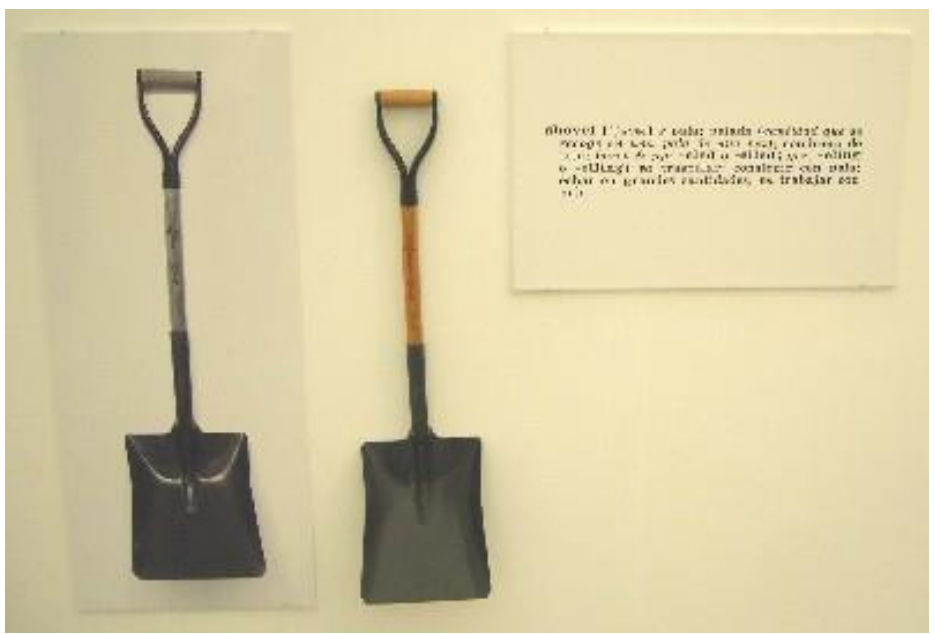

Photo 18: Joseph Kosuth,

\section{Conclusion}

A series of developments have occurred in the concept of art with the rapid development of technology in our present age. Conceptual art is a movement which addresses reason, maintains the thought in the forefront and is characterized as the art of idea as well. This movement came to be prominent in the periods when both Modernism and Postmodernism became influential. Especially the new concepts formed within our present-day art often utilizes the name postmodern. With the advent of conceptual art, we see that the waste objects have lost their meaning and that it has become necessary for the thought to be constantly questioned. Work of Art is now the thought itself.

Artwork no longer exists as a material object within this art movement. Concepts are the most essential aspect of the artwork. Despite the fact that it is difficult to attach meaning to and for the receptive to interpret the concrete products formed by the combination of concepts, the meaning that arises is unique. The boundaries of the mind are pushed by the conceptual art and despite its permanence being questioned materially its cognitive permanence continues for a long time by means of a mental filter as long as the prevalent concepts in the mind are presented through correct formal and contextual methods. Conceptual art in a constant pursuit of meaning and forcing the limits of creativity even to this day has maintained its effect on modern art because of the fact that creation in mind does not cease to exist and there is no limit to creating. 


\section{Bibliography}

ANTMEN, Ahu. 20. Yüzyıl Batı Sanatında Akımlar. İstanbul, Sel Yayıncılık. 2008

ATAKAN, Nancy. Türkiye'de Kavramsal Sanat. Doktora Tezi. İstanbul: M.S.Ü. Sosyal Bilimler Enstitüsü.1995.

CABANNE, Pierre. Dialogues With Marcel Duchamp. Translated by Çev. Ron Padgett, ABD, Da Capo Pres. 2010

EROĞLU, Özkan. Paris'te Sanat. Tolbiak 81 Notları, İstanbul, Nelli Sanatevi yayınları. 2005

http://www.nuveforum.net/451-fluxus/59795-kavramsal-sanatconceptual-art-henry-flynt-malzemesi-kavram-olan-sanat-dedi/ (26.12. 2016, 00.45)

KALKAN ERENUS, Özlem. Marcel Duchamp. İstanbul, Tekne Yayınları. 2014

KOSUTH. Joseph, Art After Philisoph. 1969

LEWITT, Sol. "Paragraphs on Conceptual Art" ; Artforum, yaz sayısı. 1967

LEWITT, Soll. Kavramsal Sanat Üzerine Tümceler, Sanat Olarak Betik. ( Çev. N. Damlacı), İstanbul, Sanat Tanımı Topluluğu Yayını. 1980

MADAN, Sarup. Post-Yapısalcıllk ve Postmodernizm. (1. Baskı). Çev: A. Baki Güçlü. Ankara: Ark Yayınları, 1997

SANOOUILLET, Michel., PETERSON, Elmer. The Writing Of Marcel Duchamp, ABD, Da Capo Pres. 2010

SÜRMELİ, Kader. "Dada Hareketinden Kavramsal Sanata" Inonu University Journal of Art and Design ISSN: 1309-9876 E-ISSN: 1309-9884 Cilt/Vol. 2 Sayı/No. 6 (2012): 337-345 Y1llık Özel Sayı/ Annual Special Issue, 2012

ŞAHINER, Rıfat. Postmodern Kırılmalar ya da Modernin Yapıbozumu. İstanbul, Yeni İnsan Yayınevi. 2008 